\title{
DAMPAK PENERAPAN ICT PADA PEMBELAJARAN IPS TERHADAP MINAT BELAJAR PESERTA DIDIK
}

\section{THE IMPACT OF ICT IMPLEMENTATION ON LEARNING IPS TOWARD THE STUDENTS' LEARNING INTEREST}

\author{
Munirah $^{1}$, Nurain Tuli ${ }^{2}$, Muh. Arif ${ }^{3}$ \\ ${ }^{1,3}$ Fakultas Ilmu Tabiyah dan Keguruan IAIN Sultan Amai Gorontalo, \\ ${ }^{2}$ SD Negeri 5 Limboto Gorontalo \\ ${ }^{1,3} \mathrm{Jl}$. Gelatik No. 1, Kota Gorontalo, ${ }^{2} \mathrm{Jl}$. Brigjend Piola Isa, Gorontalo \\ Email: munirah@iaingorontalo.ac.id ${ }^{1}$ nuraintuli@gmail.com² muharif@iaingorontalo.ac.id ${ }^{3}$
}

\begin{abstract}
Abstrak
Artikel ini bertujuan untuk mengungkap tentang dampak penerapan ICT pada pembelajaran IPS terhadap minat belajar peserta didik di SDN 2 Tabongo Gorontalo dan hambatan dalam penerapan ICT pada pembelajaran IPS. Jenis penelitian ini adalah penelitian kualitatif. Subjek penelitian ini adalah peserta didik SDN 2 Tabongo Kecamatan Tabongo Kabupaten Gorontalo. Teknik analisis data yang digunakan adalah teknik analisis deskriptif. Teknik pengumpulan data yang digunakan adalah wawancara dan pengamatan. Hasil temuan menunjukkan bahwa penerapan ICT pada pembelajaran Ilmu Pengetahuan Sosial telah mampu meningkatkan minat belajar peserta didik. Tingkat capaian persentase partisipasi siswa khusus mata pelajaran ilmu pengetahuan sosial pada tahun berjalan berkisar antara $80 \%$ sampai dengan $90 \%$. Hal ini menunjukkan bahwa penggunaan ICT sangat membantu peserta didik meningkatkan pemahaman terhadap materi yang diajarkan dan wawasannya terhadap materi yang diajarkan meningkat.
\end{abstract}

Kata Kunci: Penerapan ICT, Pembelajaran IPS, Minat Belajar

\section{Abstract}

This article aimed to determine the impact of ICT implementation on learning IPS toward the students' learning interest at SDN 2 Tabongo Gorontalo and to find the obstacles in implementing ICT on learning IPS. The research used was qualitative method with descriptive approach. The subjects were the students of SDN 2 Tabongo subdistrict Tabongo District Gorontalo. The findings showed that the implementation of ICT on IPS learning was able to increase the students' learning interest. The achievement rate of the percentage of the students' participation was $80 \%$ to $90 \%$. This result indicted that the implementation of ICT was very helpful for the students to increase their understanding of the material being taught.

Keywords: ICT Implementation, IPS Learning, Learning Interests

How to Cite: Munirah, Tuli, N., \& Arif, M. (2019). Dampak Penerapan ICT pada Pembelajaran IPS terhadap Minat Belajar Peserta Didik. AULADUNA: Jurnal Pendidikan Dasar Islam, 6(2), 156-163.

\section{Pendahuluan}

Trianto (2014: 171) mengemukakan bahwa pembelajaran IPS merupakan salah satu mata pelajaran dalam kurikulum sekolah dasar yang diajarkan mulai dari kelas I sampai kelas VI. IPS memuat tentang ilmu-ilmu sosial yang pada hakikatnya mengajarkan peserta didik agar memiliki rasa sosial tinggi dalam kehidupannya. Hermanto, Japar, \& Utomo (2019: 52) mengemukakan bahwa melalui pembelajaran ilmu sosial diharapkan siswa dapat mengetahui keragaman bangsa, keragaman budaya, sejarah bangsa, dan keadaan alam. Ilmu Pengetahuan Sosial (IPS) merupakan mata 
pelajaran yang memiliki peranan penting dalam membentuk warga negara yang baik, maka pembelajaran Ilmu Pengetahuan Sosial (social studies) sangat penting pada jenjang pendidikan dasar. Pendidikan dasar merupakan peletakan dasar/fondasi pemahaman dan keilmuan tentang bagaimana hidup bersosial karena di sekolah siswa datang dari lingkungan yang berbeda-beda, sisi lain dari itu juga bahwa kepedulian terhadap lingkungan sosial atau memiliki pengetahuan dan pemahaman tentang sosial itu bagian dari nilai-nilai pendidikan karakter bangsa. Mereka juga menjadi anggota masyarakat dengan membawa budaya yang mereka alami dan amalkan, meskipun sekolah bukanlah satu-satunya sarana untuk mengenal masyarakat, tetapi menjadi bagian yang cukup penting (Rahmad, 2016: 73).

Munir (2015: 13) mengemukakan bahwa keadaan menunjukkan belum mampu mendayagunakan potensi ICT (Information and Communication Technology) secara baik, dan oleh karena itu Indonesia terancam digital divide (kesenjangan digital) yang semakin tertinggal terhadap negara-negara maju. Kesenjangan prasarana dan sarana telekomunikasi dan informasi antara kota dan pedesaan juga memperlebar jurang perbedaan, sehingga terjadi pula kesenjangan digital di dalam negeri kita sendiri.

TIK telah menjadi salah satu media pembelajaran yang banyak digunakan untuk meningkatkan efektivitas dan efisiensi dalam proses pembelajaran (Mahdum, Hadriana, \& Safriyanti, 2019: 296). Dalam dunia pendidikan, terdapat beberapa alasan problematik yang mendasari pentingnya pemanfaatan TIK yang paling populer dan paling massal di Indonesia ini untuk percepatan peningkatan mutu pendidikan di Indonesia, yaitu permasalahan kesenjangan layanan dan disparitas mutu pendidikan, kecenderungan dan tuntutan pendidikan, perubahan sosio-budaya masyarakat, landasan teoretis dan bukti-bukti empirik, dan pengalaman Indonesia dalam pengembangan TIK.

Pembelajaran IPS dirancang untuk membimbing dan merefleksikan kemampuan peserta didik dalam kehidupan bermasyarakat yang senantiasa berubah dan berkembang terus menerus. Hal ini merupakan tantangan yang sangat berat mengingat masyarakat secara global selalu mengalami perubahan setiap saat. Oleh karena itu, diperlukan suatu pengetahuan yang dapat menunjang pengembangan kreativitas guru dalam mengajar. Hermanto, Japar, \& Utomo (2019: 182) menjelaskan bahwa pengembangan kreativitas dan kemampuan guru ditujukan untuk menghindari permasalahan yang muncul dari diri peserta didik selama mengikuti pembelajaran IPS, karena peserta didik diharapkan dapat mengembangkan kemampuan dan sikap yang rasional tentang gejala-gejala sosial serta perkembangan masyarakat Indonesia dan dunia, baik di masa lampau, masa kini, maupun masa yang akan datang. Dalam pembelajaran IPS guru harus dapat menciptakan suasana belajar yang menyenangkan dan penuh antusias bagi peserta didik.

Untuk menciptakan kegiatan pembelajaran IPS yang menyenangkan, guru sebaiknya menggunakan media belajar yang juga dapat menarik minat belajar sehingga peserta didik tidak merasa bosan selama mengikuti pembelajaran. Terkait tentang media pembelajaran maka harus menggunakan media pembelajaran tersebut dengan benar dan tepat untuk menunjang proses pembelajaran yang dilaksanakan, dalam hal ini media yang tepat dapat merangsang peserta didik untuk lebih mengerti dan memahami materi yang ada pada pelajaran IPS. Oleh karena itu, guru harus menggunakan media pembelajaran yang tidak saja membuat proses pembelajaran menjadi menarik, tetapi juga memberikan ruang bagi peserta didik untuk berkreasi dan terlibat secara aktif sepanjang proses pembelajaran sehingga aspek kognitif, afektif, dan psikomotorik peserta didik pun dapat berkembang maksimal secara bersamaan tanpa mengalami pendistorsian salah satunya. Kenyataan apa yang menjadi harapan dan tujuan di atas 
belum sepenuhnya terpenuhi. Namun usaha ke arah itu senantiasa dilakukan oleh seluruh elemen pendidikan.

Hal ini menunjukkan bahwa dengan penggunaan media yang tepat dalam pembelajaran akan menarik minat belajar peserta didik terutama pada mata pelajaran IPS. Dengan media yang menarik materi pelajaran akan mudah diserap oleh siswa, karena dengan menggunakan media dapat mempermudah pemahaman belajar anak dalam pencapaian tujuan pengajaran. Materi mengenal sejarah budaya, sosial, ekonomi, dan geografi adalah salah satu materi pada pelajaran IPS kelas IV yang terdapat dalam Kurikulum 2013, tetapi ternyata guru dalam melaksanakan pembelajaran kebanyakan masih bersifat konvensional, artinya guru masih mendominasi jalannya pembelajaran dan belum memanfaatkan media pembelajaran secara maksimal sehingga pembelajaran yang dilakukan cenderung kurang menarik peserta didik. Selain itu, guru belum sepenuhnya memanfaatkan alat peraga dalam pembelajaran Ilmu Pengetahuan Sosial. Kebanyakan masih menggunakan alat peraga standar manual seperti menggunakan gambar-gambar. Untuk mengatasi hal itu, perlu diterapkan media pembelajaran berbasis ICT. Adapun pembelajaran berbasis ICT yang dimaksudkan adalah media pembelajaran yang bisa digunakan untuk menunjang proses pembelajaran khususnya pada mata pelajaran IPS materi mengenal sejarah budaya, sosial, ekonomi, dan geografi.

Berdasarkan hasil observasi pembelajaran IPS di SDN 2 Tabongo Gorontalo menunjukkan bahwa sebelum penggunaan ICT dalam pembelajaran IPS, seluruh siswa menganggap bahwa proses pembelajaran IPS adalah menghafal materi pelajaran. Mereka beranggapan bahwa materi pelajaran IPS tidak dapat mengembangkan kemampuan berpikir, memecahkan persoalan dengan menggunakan potensi otak. Akibatnya, proses pembelajaran adalah mendengar, mencatat, dan menghafal sesuai dengan sumber belajar yang ditentukan. Asumsi inilah yang kemudian mendorong peserta didik untuk mendapatkan mata pelajaran IPS sebagai mata pelajaran hafalan yang membosankan bagi sebagian peserta didik. Penggunaan ICT di SDN 2 Tabongo Gorontalo, yakni penggunaan media yang berbasis ICT tanpa bermaksud mengesampingkan dan memandang sebelah mata media yang sudah ada. Diharapkan dengan penerapan media berbasis ICT di SDN 2 Tabongo Gorontalo lebih mewarnai proses pembelajaran agar pembelajaran lebih bermakna, bergairah, bernuansa Pembelajaran Aktif, Kreatif, Efektif, dan Menyenangkan (PAKEM), dan dapat menumbuhkan minat belajar peserta didik. Di sisi lain peserta didik pun akhirnya akan lebih akrab dan lebih menguasai komputer dan internet, sehingga harapan dalam pembelajaran berbasis ICT dapat terwujud di SDN 2 Tabongo Gorontalo. Prayitno, Kurniawati, \& Arvianto (2018) mengemukakan bahwa pada perkembangannya hingga saat ini, kemajuan ICT membawa keuntungan yang baik bagi dunia pendidikan tidak hanya terbatas pada teknologi komputer (perangkat keras dan perangkat lunak) yang digunakan untuk memproses dan menyimpan informasi, tetapi juga termasuk teknologi komunikasi untuk mengirimkan informasi.

\section{Metode Penelitian}

Moleong (2017: 4) mengemukakan bahwa jenis penelitian yang digunakan adalah penelitian kualitatif. Penelitian kualitatif adalah suatu tradisi tertentu dalam ilmu pengetahuan sosial yang secara fundamental adalah melakukan pengamatan terhadap manusia dan kawasannya dengan orang-orang tersebut dalam bahasa dan peristilahannya. Arif (1992: 21) mengemukakan bahwa pendekatan kualitatif yaitu suatu prosedur penelitian yang menghasilkan data deskriptif berupa tulisan dan perilaku yang 
dapat diamati dari subjek itu sendiri. Salah satu pendekatan dalam penelitian kualitatif yaitu pendekatan filosofis, memberikan gagasan pemikiran mendasar yang digunakan untuk menentukan objek kajian atau domain apa saja yang menjadi kajian pokok dan dimensi pengembangan sebagai pendidikan disiplin ilmu (aspek ontologis).

Jenis penelitian ini diambil dari data tertulis, rekaman, atau pengambilan foto. Pencatatan sumber data ini melalui wawancara dari beberapa narasumber yaitu kepala sekolah dan seluruh staf dewan guru SDN 2 Tabongo. Selain itu, dilakukan pengamatan yang merupakan hasil gabungan dari melihat, mendengarkan, dan bertanya. Jawaban dari pertanyaan yang dilontarkan pada subjek penelitian dicatat sebagai data utama ditambah dengan hasil pengamatan dari tindakan subjek penelitian yaitu peserta didik SDN 2 Tabongo Kecamatan Tabongo Kabupaten Gorontalo. Teknik analisis data yang digunakan dalam penelitian ini adalah teknik deskriptif dengan membuat gambaran yang dilakukan dengan cara reduksi data atau penyederhanaan (data reduction), paparan/sajian data (data display), dan penarikan kesimpulan (Arifin, 1996: 10).

Reduksi data adalah proses pemilihan, pemusatan perhatian pada penyederhanaan, pengobservasian, dan transformasi data mentah/data kasar yang muncul dari catatan-catatan tertulis di lapangan. Reduksi data dilakukan dengan membuat ringkasan, mengembangkan sistem pengkodean, menelusuri tema, membuat gugus-gugus, dan menuliskan memo.

\section{Hasil Penelitian dan Pembahasan}

\subsection{Penerapan ICT pada Pembelajaran IPS di SDN 2 Tabongo Gorontalo}

Hasil wawancara dengan S1 menyatakan bahwa IPS sebagai salah satu ilmu pengetahuan yang berkaitan dengan perkembangan kehidupan manusia baik dari segi ekonomi, hubungan sosial, budaya, sejarah, hukum maupun interaksinya dengan lingkungan alam sangat erat kaitannya dengan tingkat peradaban manusia, termasuk teknologi masa kini. Semua aspek kehidupan manusia itu adalah objek kajian IPS. Untuk itu agar dapat memperjelas materi pembelajaran yang demikian luas dan senantiasa mengalami perkembangan ini, maka teknologi informasi dan komunikasi (TIK) yang berkembang sekarang sangat mendukung.

Abdullah, Mobonggi, Solong, \& Arif (2019) mengemukakan bahwa Teknologi Informasi dan Komunikasi atau ICT merupakan salah satu terobosan dari dunia pendidikan dalam peningkatan pemanfaatan teknologi informasi yang tidak dapat dipisahkan dengan dunia informasi teknologi sekarang, sering dikenal dengan digital device atau teknologi digital yaitu teknologi yang menggunakan dan memanfaatkan internet sebagai sarana pembelajaran dan menggunakan fasilitas web yang tersedia di situs dari sebuah organisasi ataupun institusi pendidikan. (Setyorini, 2015: 90) mengemukakan bahwa hadirnya ICT (Information and Communication Technology) atau yang sering dikenal sebagai TIK (Teknologi Informatika dan Komunikasi) di sekolah, di ruang kelas, dan di rumah mempunyai potensi yang sangat besar untuk dimanfaatkan dalam dunia pendidikan. Pada blue print TIK Depdiknas, setidaktidaknya disebutkan ada tujuh fungsi TIK dalam pendidikan, yakni sebagai sumber belajar, alat bantu belajar, fasilitas pembelajaran, standar kompetensi, sistem administrasi, pendukung keputusan, dan infrastruktur.

Hasil wawancara dengan S2 menjelaskan bahwa penerapan ICT dalam pembelajaran IPS memang sangat diperlukan karena pelajaran ilmu pengetahuan sosial selalu berkaitan dengan sejarah masa lalu, akan lebih konkret dan mudah dipahami apabila disampaikan oleh guru dengan gambar-gambar foto, film dokumenter, atau 
animasi seperti hewan purbakala. Kondisi cuaca dan iklim akan lebih menarik apabila siswa disuguhi film cuaca ekstrim yang terjadi di beberapa belahan dunia, sehingga siswa mengetahui perubahan iklim yang sebenarnya. Berdasarkan hasil wawancara dengan S3 diperoleh bahwa penerapan ICT dalam pembelajaran IPS di SDN 2 Tabongo dilakukan sebagai upaya untuk meningkatkan pemahaman siswa pada saat pembelajaran. Penerapan ICT dalam pembelajaran IPS dimaksudkan agar proses pembelajaran bukan hanya menarik, tetapi juga memberikan ruang bagi peserta didik untuk berkreasi dan terlibat secara aktif sepanjang proses pembelajaran sehingga aspek kognitif, afektif, dan psikomotorik peserta didik pun dapat berkembang maksimal secara bersamaan tanpa mengalami hambatan.

Selanjutnya hasil wawancara dengan S4 menyatakan bahwa dalam pembelajaran di kelas jika menggunakan ICT dapat memudahkan siswa untuk mengetahui atau memahami materi. Sesuai dengan penuturan responden, kegiatan pembelajaran jika menggunakan ICT dapat meningkatkan minat belajar siswa. Selanjutnya, wawancara dengan S5 menyatakan bahwa dalam pembelajaran IPS guru sering menggunakan ICT dalam menyampaikan materi sehingga apa yang dijelaskan oleh guru lebih menarik. S6 mendukung pendapat tersebut dan mengatakan bahwa guru sering menjelaskan materi dengan menampilkan gambar-gambar melalui media LCD sehingga siswa dapat melihat secara langsung apa yang dijelaskan tanpa membayangkan.

Pendapat di atas menunjukkan bahwa guru telah menerapkan ICT dalam pembelajaran IPS sehingga apa yang disampaikan oleh guru dapat diterima dan dipahami oleh siswa. Dengan demikian, penerapan ICT pada mata pelajaran IPS sangat diperlukan dikarenakan siswa tidak hanya mendengarkan tetapi dapat langsung melihat dan mempraktikkannya.

\subsection{Minat Peserta Didik pada Pembelajaran IPS melalui Penggunaan ICT di SDN 2 Tabongo Gorontalo}

Berdasarkan hasil wawancara dengan S4, penerapan ICT pada pembelajaran Ilmu Pengetahuan Sosial dimaksudkan agar siswa dapat memahami serta mengaktualisasikan materi yang diajarkan. Kondisi ini diharapkan dapat berimplikasi pada minat belajar peserta didik. Hasil wawancara yang dilakukan dengan S4 bahwa penerapan ICT dalam pembelajaran ilmu pengetahuan sosial secara optimal mampu menumbuhkan minat belajar siswa. Tingkat capaian persentase partisipasi siswa khusus mata pelajaran ilmu pengetahuan sosial pada tahun berjalan khusus untuk kelas I sampai dengan VI berkisar antara 80\% sampai dengan 90\%. Pendapat ini menunjukan bahwa masih terdapat siswa yang belum aktif dalam pembelajaran secara individu. Hal ini menunjukan bahwa perlu analisis yang lebih mendalam terhadap penerapan ICT pada pembelajaran ilmu pengetahuan sosial. Analisis tersebut dilakukan untuk lebih memaksimalkan aplikasi ICT di lapangan.

Dalam pelaksanaan pembelajaran IPS di SDN 2 Tabongo Gorontalo berdasarkan hasil observasi sebelum penggunaan ICT dalam pembelajaran IPS, seluruh siswa menganggap bahwa proses pembelajaran IPS adalah menghafal materi pelajaran. Mereka beranggapan bahwa materi pelajaran IPS tidak dapat mengembangkan kemampuan berpikir dan memecahkan persoalan dengan menggunakan potensi otak. Akibatnya, proses pembelajaran adalah mendengar, mencatat, dan menghafal sesuai dengan sumber belajar yang ditentukan. Asumsi inilah yang kemudian mendorong peserta didik untuk mendapatkan mata pelajaran IPS sebagai mata pelajaran hafalan yang membosankan bagi sebagian peserta didik. Penggunaan media yang berbasis ICT 
di SDN 2 Tabongo Gorontalo tanpa bermaksud mengesampingkan ataupun memandang sebelah mata media yang sudah ada. Diharapkan dengan penerapan media berbasis ICT di SDN 2 Tabongo Gorontalo lebih mewarnai proses pembelajaran agar pembelajaran lebih bermakna, bergairah, bernuansa Pembelajaran Aktif, Kreatif, Efektif dan Menyenangkan (PAKEM), dan dapat menumbuhkan minat belajar peserta didik. Di sisi lain, peserta didik pun akhirnya akan lebih akrab dan lebih menguasai komputer dan internet, sehingga harapan dalam pembelajaran berbasis ICT dapat terwujud di SDN 2 Tabongo.

Berdasarkan hasil wawancara dengan S1 bahwa siswa sangat senang dengan penggunaan ICT dalam pembelajaran ilmu pengetahuan sosial karena sangat membantu untuk meningkatkan pemahaman terhadap materi yang diajarkan. Hal senada dengan pandangan di atas dikemukakan oleh S7 bahwa penggunaan ICT sangat membantu peserta didik meningkatkan pemahaman terhadap materi yang diajarkan dan wawasannya terhadap materi yang diajarkan bertambah. Pandangan ini menunjukkan bahwa siswa akan memahami materi yang diajarkan dengan menggunakan ICT pada saat pembelajaran berlangsung. Mencermati hal ini maka penerapan ICT perlu dilakukan secara rutin karena sangat membantu untuk meningkatkan pemahaman siswa terhadap pelajaran yang disajikan guru. Hal ini pada gilirannya akan sangat membantu dalam meningkatkan minat belajar siswa dalam belajar.

Berdasarkan hasil wawancara dengan S4 bahwa untuk siswa kelas IV sampai dengan kelas VI dalam pembelajaran Ilmu Pengetahuan Sosial dengan menggunakan ICT sebagian telah tuntas dalam belajar. Hal tersebut ditunjukkan oleh tingkat ketuntasan belajar yang secara keseluruhan berkisar antara angka 85\% sampai $90 \%$. Responden ini menjelaskan bahwa untuk menentukan minat belajar siswa dalam belajar dilakukan dengan cara melihat partisipasi mereka dalam belajar.

Berdasarkan uraian di atas, jelas menunjukkan bahwa penerapan ICT dalam pembelajaran ilmu pengetahuan sosial telah memberi dampak positif dalam menarik minat belajar siswa.

\subsection{Hambatan dalam Penerapan ICT pada Pembelajaran IPS}

Penerapan ICT dalam pembelajaran IPS memiliki hambatan. Kondisi ini telah menjadi hal lumrah yang sering ditemui dalam implementasinya pada saat pembelajaran. Adapun hambatan dalam penerapan ICT sebagaimana hasil wawancara dengan S1 bahwa dalam penerapan ICT memerlukan alat pendukung seperti listrik. Di beberapa daerah, termasuk Gorontalo, listrik menjadi kendala/hambatan bukan hanya pada dunia pendidikan, tetapi juga di dunia industri. Pendapat ini menunjukkan perlunya perhatian dari pihak kepala sekolah bahkan dinas pendidikan untuk menyiapkan alat penyuplai listrik untuk setiap sekolah agar lebih memudahkan dalam penggunaan ICT pada pembelajaran.

Hasil wawancara dengan S2 mengemukakan bahwa hambatan yang dialami dalam penerapan ICT pada pembelajaran IPS adalah penggunaan ICT yang kurang optimal. Dalam konteks ini, terdapat guru yang kurang paham dalam penggunaan ICT. Hal ini menyebabkan penerapan ICT hanya terbatas kepada guru yang dapat mengoperasikan ICT. Hal senada juga disampaikan oleh S8 bahwa hanya guru tertentu yang sering menggunakan ICT pada saat pembelajaran berlangsung, sehingga siswa sering merasa iri bahkan bosan dalam belajar. Pandangan ini menunjukkan bahwa guru seharusnya dapat mengusai dan mengoperasikan ICT agar dalam setiap pembelajaran 
dapat diterapkan untuk memudahkan siswa dalam memahami setiap materi yang disampaikan oleh guru.

Berdasarkan uraian di atas, jelas bahwa secara umum penerapan ICT pada mata pelajaran Ilmu Pengetahuan Sosial memiliki sejumlah hambatan. Berbagai hambatan dari penerapan ICT perlu diantisipasi sehingga memaksimalkan penerapan ICT di sekolah. Melalui kegiatan yang dilakukan secara intensif, maka berbagai kelemahan dalam penerapan ICT dapat diantisipasi sehingga keberadaan media ini secara optimal mendukung minat belajar peserta didik khususnya dalam mata pelajaran Ilmu Pengetahuan Sosial.

Khodijah \& Nurizzati (2018: 165) mengemukakan bahwa dengan adanya perkembangan teknologi informasi dan komunikasi di dalam dunia pendidikan, maka akan membantu dan mempermudah peserta didik dalam proses belajar. Peserta didik dapat dengan mudah mencari bahan-bahan materi pelajaran dimanapun dan kapanpun tanpa terbatas ruang dan waktu.

\section{Simpulan}

Secara umum penerapan ICT dalam pembelajaran telah dilakukan oleh guru. Penerapan ICT dalam kegiatan pembelajaran IPS dapat meningkatkan minat belajar siswa. Hal ini dapat dilihat dari keaktifan siswa dalam belajar dan juga dilihat dari hasil belajar siswa yang meningkat. Mencermati hal ini maka perlu langkah proaktif dalam menerapkan ICT dalam pembelajaran. Penerapan ICT pada pembelajaran ilmu pengetahuan sosial telah mampu meningkatkan minat belajar siswa. Adapun hambatan yang dialami dalam penerapan ICT pada pembelajaran IPS adalah perlu adanya penyuplai listrik di sekolah dan kurangnya guru yang dapat mengoperasikan ICT.

\section{Daftar Pustaka}

Abdullah, S., Mobonggi, A., Solong, N. P., \& Arif, M. (2019). Implikasi Teknologi Informasi Komunikasi terhadap Prestasi Belajar Peserta Didik pada Kelompok Mata Pelajaran Agama. Jurnal Ilmiah AL-Jauhari: Jurnal Studi Islam dan Interdisipliner, 4(1), 172-193. https://doi.org/doi.org/10.30603/jiaj.v4i1.761

Arif, F. (1992). Pengantar Metode Penelitian Kualitatif. Surabaya: Usaha Nasional.

Arifin, I. (1996). Penelitian Kualitatif. Bandung: Kalimasahada Press.

Hermanto, Japar, M., \& Utomo, E. (2019). Implementasi Pembelajaran Ilmu Pengetahuan Sosial (IPS) dalam Membentuk Karakter Siswa. AULADUNA: Jurnal Pendidikan Dasar Islam, 6(1), 1-6. https://doi.org/doi.org/10.24252/ 10.24252/auladuna.v6i1a1.2019

Khodijah, S., \& Nurizzati, Y. (2018). Dampak Penggunaan Teknologi Informasi dan Komunikasi terhadap Perilaku Sosial Siswa di MAN 2. Jurnal Edueksos, 7(2), 161-176. https://doi.org/10.24235/edueksos.v7i2.3370

Mahdum, Hadriana, \& Safriyanti, M. (2019). Exploring Teacher Perceptions and Motivations to ICT use in Learning Activities in Indonesia. In Journal of Information Technology Education: Research (Vol. 18, pp. 293-317). https://doi.org/doi.org/10.28945/4366

Moleong, L. J. (2017). Metodologi Penelitian Kualitatif. Jakarta: Remaja Rosdakarya.

Munir. (2015). Dampak Teknologi Informasi dan Komunikasi (TIK) dalam Dunia pendidikan di Indonesia, 1-13. Retrieved from http://file.upi.edu/Direktori 
/FPMIPA/PRODI._ILMU_KOMPUTER/196603252001121-MUNIR/Artikel_ TIK/Dampak_Teknologi_Informasi_dan_Komunikasi_dalam_Pendidikan.pdf Prayitno, E., Kurniawati, D., \& Arvianto, I. R. (2018). Pemanfaatan Teknologi Informasi dan Komunikasi (TIK) untuk Meningkatkan Kualitas Pembelajaran. Seminar Nasional Call for Paper \& Pengabdian Masyarakat, 1(1), 401-414. Retrieved from http://jurnal.untag-sby.ac.id/index.php/semnasuntag/article/ download/1689/1434

Rahmad. (2016). Kedudukan Ilmu Pengetahuan Sosial (IPS) pada Sekolah Dasar. MUALLIMUNA: Jurnal Madrasah Ibtidaiyah, 2(1), 67-78. https://doi.org /dx.doi.org/10.31602/muallimuna.v2i1.742

Setyorini, R. (2015). Pemanfaatan Internet sebagai Implementasi ICT dan Sarana Memotivasi Belajar Sastra di Sekolah. In Prosiding Seminar Nasional Teknologi Pendidikan (pp. 89-101). Retrieved from http://jurnal.fkip.uns.ac.id/index. php/psdtp/article/view/9053/6727

Trianto. (2014). Model Pembelajaran Terpadu. Jakarta: Bumi Aksara. 